\title{
単一植物細胞の電気的特性に関する研究 II
}

滲透現像に件う原形質膜及び細胞液の扯抗の変化について*

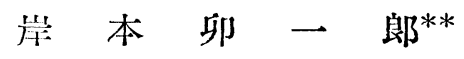

Uichirô Kishimoto: Studies on the Electrical Properties of a Single Plant Cell II Changes in the Resistance of Protoplasmic Membrane and of Cell Sap

Accompanying Osmosis

1954 年 9 月 30 日受付

第 1 報に括いて,フラスモの節間細胞つ細胞液 の抵抗 $\left(\gamma_{2}\right.$ オーム) と原形質膜の抵抗 $(\gamma$ オーム) の变化が，インピーダンスの測定から同時に計算 できることを示した。即ち全体のインピーダンス を, $Z=Z_{R}-j Z_{X}$ とすると, 細胞液の抵抗の変 化については,

$$
\frac{\Delta r_{2}}{r_{2}}=\frac{\Delta Z_{R}}{Z_{R}}
$$

の関係があり, 原形質膜の抵抗については,

$$
\frac{\Delta r}{r}=\frac{1}{2-\omega \mathrm{C}_{3} Z_{X}} \cdot \frac{\Delta Z_{X}}{Z_{X}}
$$

の関係がある。この式は通常近似的に

$$
\frac{\Delta r}{r}=0.74 \frac{\Delta Z_{X}}{Z_{X}}
$$

で表わされるが， $Z_{X}$ が非常に大きくなつたとき は, $\Delta Z_{X} / Z_{X}$ の係数は更に大きい值となる。

本研究に怙いては, 筆者が導いたこれらの関係 式を用いて透現象に伴了原形質膜及び細胞液の 抵抗の変化を調べた。㴽透現象に関しては既に多 くの実験がなされているが，この現象と原形質膜 の透過性との関連については確実なデータが少 い。上述の方法によれば，細胞になんら害作用を 与えることなく，連続的に原形質膜のイォン透過 性の变化と, 細胞液の電気伝導度, つまりイオン 濃度の变化を同時に知ることができる。

* 本研究は昭和 29 年度交部省科学研究助成金 の援助を受けた

** 大阪大学理学部生物学教室

*** この材料は京都大学植物学教室より提供され た

\section{実 験 方 法}

実験はヒメフラスモ (Nitella fiexilis)*** の節 間細胞を材料として,これを Fig. 1 に示すような 3 つのプールをもつパラフイン製の容器に入れて 行つた。プール A， B，Cには通常 $10^{-2} \mathrm{M} \mathrm{KCl}$

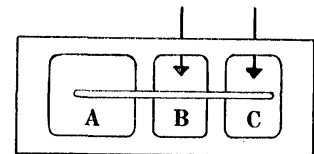

Fig. 1. A vessel used for the impedance measurement.

水溶液を充たし，更に $\mathrm{A}$ 又は $\mathrm{B}, \mathrm{C}$ に適当量の 蔗糖を添加し，そのときに現れる B, C 間のイン ピーダンスの帘化を第 1 報にのべたよろにホイー

トストン橋によつて測定した。用いた周波数は $1000 \mathrm{c} / \mathrm{s}$ である。

\section{実験結果及び考察}

一つの細胞の異つた部分が上述のようにそれぞ れ異つた涹透圧をるつ溶液に接すると, 細胞内に 水の移動が起ることが Osterhout (1949), 神谷, 田沢, 黒田 (1952) によつて報告されたが，細胞 から水が出る場合と, 細胞に水が入る場合とで原 形質膜の抵抗がいかに変化寸るかを調へるために 本実験を行つた。実験の順序を外液の組成によつ て示すと次の通りである。
A

I. $10^{-2} \mathrm{M} \mathrm{KCl}$

II. $10^{-2} \mathrm{M} \mathrm{KCl}+n \mathrm{M}$ Sucrose

III. $10^{-2} \mathrm{M} \mathrm{KCl}$

IV. $10^{-2} \mathrm{M} \mathrm{KCl}$

V. $10^{-2} \mathrm{M} \mathrm{KCl}$
B そ C $10^{-2} \mathrm{M} \mathrm{KCl}$ $10^{-2} \mathrm{M} \mathrm{KCl}$ $10^{-2} \mathrm{M} \mathrm{KCl}$ $10^{-2} \mathrm{M} \mathrm{KCl}+n \mathrm{M}$ Sucrose $10^{-2} \mathrm{M} \mathrm{KCl}$ 


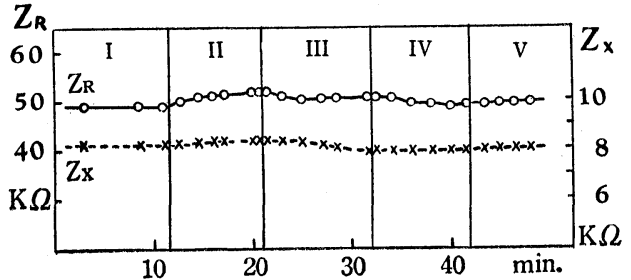

Fig. 2. a

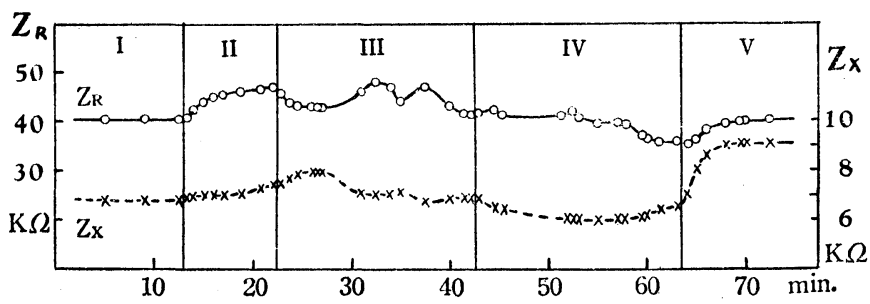

Fig. 2. b

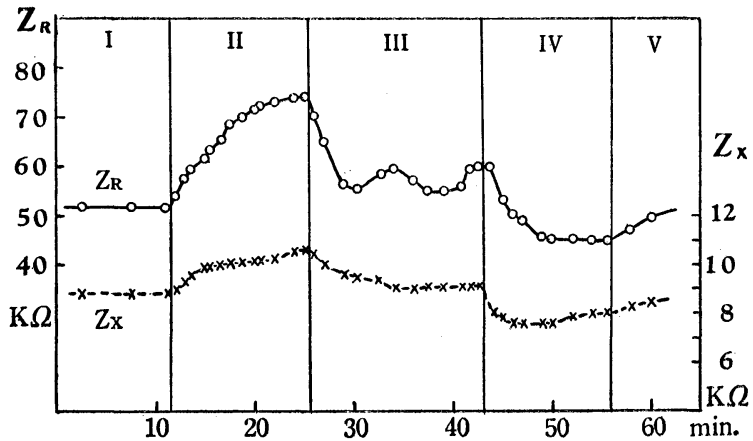

Fig. 2. c

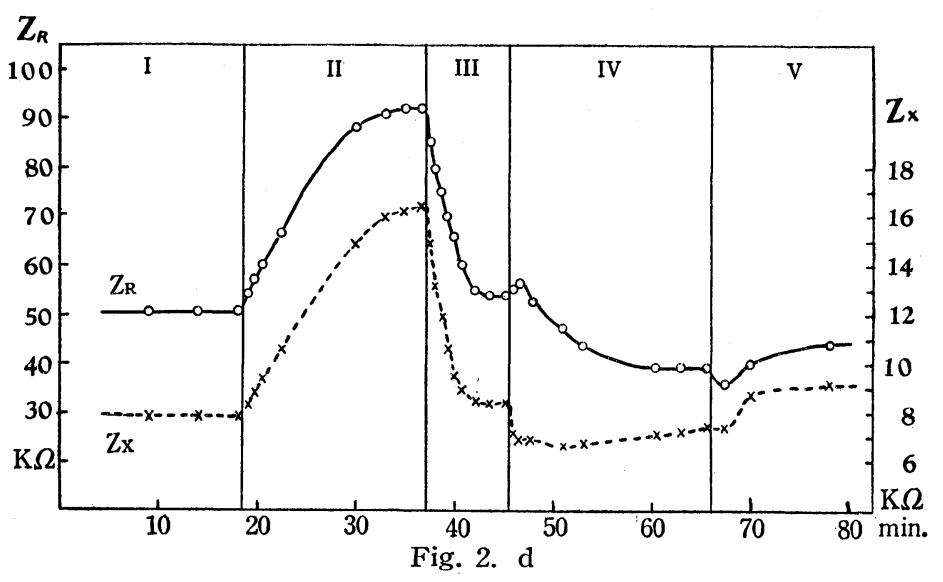

この過程で示されている よろに，白金電極が設けら れているプール B，C は常 に同一成分，同一濃度の溶 液をすつて充されている。 このような処理によつて細 胞から水が出る場合と細胞 に水が入る場合に起る原形 質膜と細胞使の抵抗の变化 を測定することができる。 各過程について順を追つて 說明すると次のようにな る。

I. A と B, C 間に滲透 圧の美のないときは細胞内 においては水の移動は起ら ず, 従つて勿論 $Z_{R}, Z_{X}$ は 変化しない。この定常性は 非常によく，少くとも8時 間以上は保たれる。

II. $\mathrm{A}$ 側の外液の透圧 を $\mathrm{B}, \mathrm{C}$ 側のそれより大き くすると，この細胞の両半 に拈ける吸水力の差によつ て水は $\mathrm{B}, \mathrm{C}$ 側より細胞内 に入り $\mathrm{A}$ 側より出てゆく。 このとき水の移動に伴つて 細胞液内では溶質の移動が 起り, $\mathrm{A}$ と $\mathrm{B}, \mathrm{C}$ 側の細胞 の吸水力が等しくなるに到 つて氷の移動は止夕定常状 態となる。この場合は水が 原形質膜を通つて 細胞内一 入る過程のインピーダンス を測定している。

III. $\mathrm{B}, \mathrm{C}$ 側の外液を元 の 10-2 $\mathrm{M} \mathrm{KCl}$ 水溶液に杘 すと, II に於て細胞液内て できていたイオン又は溶質 の濃度勾配が細胞の両半に 前と区対の向に吸水力の差 を生ぜしめる。従つて水は $\mathrm{A}$ 側より細胞内に大り $\mathrm{B}, \mathrm{C}$ 側より出てゆく。水の移動 


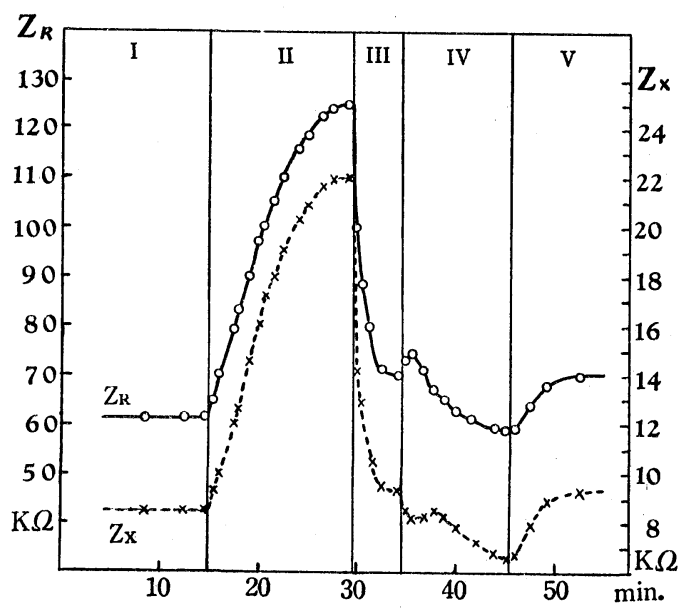

Fig. 2. $\mathrm{e}$

Fig. 2. Time courses of changes in the impedance $\left(Z=Z_{R}-j Z_{X}\right)$ during osmosis. a, b, c, d, and e show the cases of the osmotic gradients of $0.1,0.2,0.3,0.4$, and $0.5 \mathrm{Mol}$ respectively. Numbers I-V correspond to the processes explained in the text. No osmosis occurs in I. Endosmosis occurs in II and V. Exosmosis occurs in III and IV. At $25^{\circ} \mathrm{C}$.

は細胞の両半に颃ける吸水力の差が無くなつた所 で止む。この場合は水が細胞より出てゆく過程の インピーダンスを測定している。

IV. 次に A はその方にして, B, C 側の外 液の滲透圧を高めると，丁度 II と逆の条件にな つて, 水が細胞より出てゆく過程のインピーダン スを測定することになる。

V. 最后に $\mathrm{B}, \mathrm{C}$ 側の外液をるとの $10^{-2} \mathrm{M}$ $\mathrm{KCl}$ に戻すと,IV に执いてできていた細胞夜内の イォン, 溶質の濃度勾配によつて水は $\mathrm{B}, \mathrm{C}$ 側よ り細胞内に入り A 側より出てゆく。この場合は III と逆の条件にあつて水が細胞内に入る過程の インピーダンスを測定している。

蕉糖溶液の濃度を $0.1,0.2,0.3,0.4,0.5 \mathrm{M}$ の 5 段階に変之, 各々の場合について以上の実験 を行つた結果を Fig. 2. に示す。これを見ると， 細胞より水が出る場合には $Z_{R}, Z_{X}$ 共に減少し, 細胞内に水が入る場合にはこれらは共に增加して いる。これらの過程に沶いて, 細胞内の㳵圧が 局部的に変ると原形質流動も一時乱されるが，外 液の唀勾配をとり去れば次第に元の正常な流動
を回復するようになる。

以上の過程に抲ける水の移動量, 移動速度に 関しては, 神谷, 田沢, 黒田(1952)によつて詳細 な実験,計算がなされて招り,水の移動に伴了溶 質の移動に関しては, 神谷, 黒田の実験 (1953) がありをたた涹唀に伴う電位差変化については 西崎の報告（1954）がある。第 3 図に示すよう にこの細胞を $2 つ に$ 仕切り（A 側： $1_{1} \mathrm{~cm}, \mathrm{~B}$ 側： $\mathrm{l}_{2} \mathrm{~cm}$ ), A 側の外液の沴透圧を B 側に比 ベて $n$ モル高く寸ると, 前にのべたように水 は B 側より細胞内に大り A 側より出てゆく。

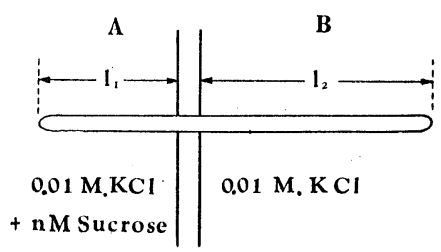

Fig. 3.

この水の移動に伴つて, 細胞内では溶質, イォン は $\mathrm{A}$ 側 に運ばれ, 両半の細胞の吸水力が等しく なれば水の移動は止久定常状態となる。この時迄 に B 側で $x$ モルの溶質の減少が岁つたるのとす れば, 定常状態に执いては次の条件が成立する。

$$
\begin{gathered}
(0.26-x)-0.01=\left(0.26+\frac{l_{2}}{l_{1}} x\right) \\
-(0.01+n)
\end{gathered}
$$

こつに示した 0.26 なる值は細胞内部の元の滲透 圧であり，蔗糖水溶液を用いて原形質分離の力法 によつて決定したもので, 個体による美は極めて 少い。この式より $x$ を求めると,

$$
x=\frac{n}{1+\frac{l_{2}}{l_{1}}}
$$

となる。この式を用い第 2 困に示した各々の場合 についての細胞液内の溶質の移動量, 従つてイオ ン浱度の変化の割合を計算すると, 表 I に示す よろになる。

細胞内一水が入る過程 (II) について, 細胞液中 の溶質或はイオンの濃度变化の計算值（第 1 表） そ, 原形質膜及び細胞夜の電気抵抗の变化の実測 値 (Fig. 2.) との関係を示すと, Fig. 4.のように 


\begin{tabular}{|c|c|c|c|}
\hline 沴透勾配 & $\begin{array}{c}\mathrm{A} \text { 側の細胞の長さ } \\
l_{1}\end{array}$ & $\begin{array}{c}\mathrm{B} \text { 側の細胞の屒さ } \\
\mathrm{l}_{2}\end{array}$ & $\begin{array}{l}\mathrm{B} \text { 側の細胞液内の } \\
\text { 溶質の濃度变化 }\end{array}$ \\
\hline 0.1 モル & $11.0 \mathrm{~mm}$ & $15.0 \mathrm{~mm}$ & $16.3 \%$ \\
\hline $0.2 \prime \prime$ & $8.5 \quad 11$ & $16.0 \quad " \prime$ & $26.7 \quad \prime \prime$ \\
\hline $0.3 \prime \prime$ & $19.0 \quad "$ & 24.0 & $51.0 \quad " \prime$ \\
\hline $0.4 \quad \prime \prime$ & $15.0 \quad \prime \prime$ & 14.5 & $79.6 \quad \prime \prime$ \\
\hline $0.5 \prime \prime$ & $17.0 \quad \prime \prime$ & $17.0 \quad \prime \prime$ & $96.4 \quad \prime \prime$ \\
\hline
\end{tabular}

なる。この図より細胞液の電気抵抗が，細胞液中 の溶質或はイオンの濃度に比例して変化している ことが判る。この結果は当然予想されることでる あが，こ〉に注目すべきことは，この值線が原点

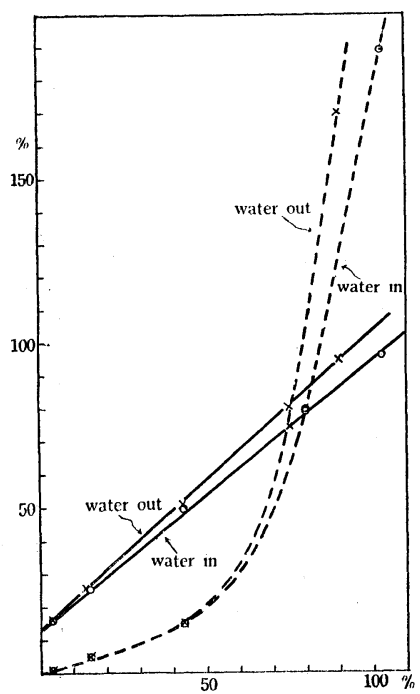

Fig. 4. Relation between the changes in the resistance of the cell sap (measured) and of the ionic concentration in the cell sap. The relation between the changes in the resistances of the protoplasmic membrane and of the cell sap is also shown. - Concentration decrease (calculated) of cell sap on B side(in per cent).

..... Resistance increase of protoplasmic membrance on B side (in per cent).

を通らないことである。これは外液の滲透勾配が 小さいときには, 細胞夜内のイオンの濃度変化が 原形質流動による攪伴作用のため減秌され, 未だ 完全に平衡に達して特らず，従つて電気抵抗が計
算より予想られる程には変化しないことによるも のと考えられる。外液の滲透勾配が大きくなり， 細胞液内の溶質或はイオンの濃度变化が大きくな ると, 定常状態が速く達成さされるようになり, 計 算值と夷測值とは良く一致する。

Fig. 4. に示されているように細胞液のイオン濃 度の変化が小さいときには，原形質膜の電気抵抗 の変化す小さいが, 前者の大きいときには後者 は非常に大きくなる。即ち簡単な直線関係では なく，圀にみられるような原点を通り下にあであ る一つの曲線で表わされることは與味深い。

再び Fig. 2. にもどると, 細胞より水が出てゆ く過程（III, IV）に扣いて一時的な原形筫膜の抵 抗の減少, 細胞液の抵抗の増加が現れて扣り,こ れは一時的に細胞よりイォンの leakage があつた ことを示している。即ち滲透勾配の小さいときに は,この leakage の現象を数回繰り返して定常状 態に達するのがみられる。(Fig. 2. b, c, III)こ れに伴つて原形質膜の抵抗が一種の減衰振動的な 变化をしている。滲透勾配が大きくなると，III の遮程が速やかに起るためこの種の变化ははつき りとは観察できないが，滲透勾配の小さいときに 著しくなかつた IV の過程の初期の leakage の 現象が眀瞭に現れる。（Fig. 2. d, e, IV）外液を もとの浚液にもどしたとき抵抗值がすとの值にも どらなかつたのは，このイオンの leakage にも とづくものと考之られる。

働作流を生ずる場合には，一時的にイオンの leakage があるが，一般に直ちに回復してもとの 状態に戻る。しかしこの実験のようにイオンの leakage を起させる原因が相当長時間作用してい るときには，細胞に対して多少とも有害な影響を 与える。（II）の過程において水が細胞内に入る につれて原形質膜の抵抗は増加し, 一応定常状態 
に達するが，更に長時間観察しているとやがて次 第に減少するようになる。しかもこの現象は滲透 勾配の大きいとき程著しく現れる。これは水の出 る側で起つたイオンの leakage の現象が細胞に 対して有害な作用を及济し，この影響が次第に水 の入る側にも及んで来たことによると考えられ る。

\section{要約}

フラスモ（Nitella flexilis）の節間細胞を用い $\tau$, 滲透現象に伴了原形質膜及び細胞液の電気抵 抗の変化について調べた。

この細胞を $2 つ の$ 部分に分ち, この間に蔗糖水 溶液で滲透勾配を与えると，水は低滲透圧側より 細胞に入り，細胞内を通つて高滲透圧側へ移動す
る。これに伴つて，細胞内ではイォン，溶質が高 滲透圧側へ運ばれる。このとき細胞液の電気抵抗 は低滲透圧側では高く，高滲透圧側では低くなり， 且つその変化は運ばれた溶質の量に比例してい る。原形質膜の抵抗す水の入る側では高くなり, 水の出る側では低くなるが，その変化の割合は渗 透勾配の小さいときは小さいが，洷透勾配が大き くなると非常に大きく变化する。

細胞へ水が入るときには，原形質膜に対して著 しい影響はみられないが，細胞より水が出てゆく ときには多少ともイォンの leakage を伴い,こ の leakage の現象は細胞に対して有害に作用す る。

本研究を行らにあたつて終始変ら始指導と鞭撻 を戴いた神谷宣郎教授に厚く御礼を申し上げる。

\section{Summary}

In the present report changes in the electric resistance of protoplasmic membrane and of cell sap under osmosis were studied.

When one end of the cell of Nitella is subjected to a higher osmotic pressure while the other end of the same cell is under a lower osmotic pressure, water passes through the cell from the hypotonic side to the hypertonic side. This process is accompanied with increase in the resistance of cell sap and of protoplasmic membrane at the part of the cell where water enters; their resistances decrease at the other end where water goes out of the cell.

The change in the ionic conductivity of the cell sap coincides very well with the calculated value of the change in the ionic concentration of the cell sap. The change in the resistance of the protoplasmic membrane is very small under lower osmotic gradient, but increases rapidly under higher osmotic gradient.

When water enters the cell, no remarkable effect is detected as to the resistance of the protoplasmic membrane. On the contrary, when water goes out of the cell, ions leak more or less out of the cell together with water, which gives unfavorable effects on the protoplasmic membrane.

\section{引用文献}

1. 神谷・田沢・黒田.（第 17 回日本植物学会大 会, 1952)

2. 神谷・黒田. (第 18 回日本植物学会大会, 1953)
3. Osterhout. W. J. V. Jour. Gen. Physiol. 32 553-557 (1949)

4. 西崎. Cytologia (1954) (in press) 